\title{
Translating the Qur'ān: An Analysis of Discourse on Hijäb in Selected English Translations
}

Ubaid.VPC

\begin{abstract}
Translation of a text from its original language to another requires not only great skill in both languages, but also in depth knowledge of the background and culture as well. A scripture, particularly the Qur'ān, which proclaims itself as a linguistic marvel, presents a higher level of difficulty. Translating Qur'än is different from all other texts and scriptures. The Words of God cannot be presented in any human language and it is difficult to have the formal and dynamic equivalence. A comparative analysis of different versions of translation of the Qur'änic verse Al Nūr 24:31 related to Hijäb is attempted here. The selected translations for the study are those rendered by Yusuf Ali (apologetic and pseudo-rational), Hilali and Muhsin Khan (salafi), Abul Ala Maududi (traditional), Muhammad Asad (apologetic) and Tarif Khalidi (modern). The paper aims to explore the differences of translating the selected verse in five representative English translations. The paper looks at the various aspects of translation like ideological insertion, discourse and translation, culture and translation and formal and dynamic equivalence.
\end{abstract}

Key Words: the Qur'ān, English Translations, Discourse on Hijāb

\section{Introduction}

A large number of the Qur'ānic verses refer to women. Islam gives a proper position to women in the socio-cultural domains of life. Women, being a social individual, occupy a particular stance in all civilizations of the world. Different viewpoints of different societies and cultures towards women are subjected to discussion 
in modern cultural discourses.

In education, according to Islamic tradition, a number of women among the early believers had a role in the transmission of the text of the Qur'ān and Sunnah and through the centuries women learned the Qur'ānic text. ' In the spiritual realm, women and men are regarded in the Qur'ān as equal in the eyes of the God, having similar religious duties. A large number of verses are addressed to the believing men and believing women and the hypocritical men and hypocritical women as well as the idolatrous men and idolatrous women. ${ }^{2}$ For instance in Al Aḥzāb 33:35 Allah says:

God promises forgiveness and a great reward to the men and women who surrender to God, the men and women who have faith, the men and women who are obedient, the men and women who are truthful, the men and women who are patient, the men and women who humble themselves (before Him), the men and women who give in charity, the men and women who fast, the men and women who guard their chastity and the men and women who remember God much. ${ }^{3}$

\section{A.R. Kidwai observes:}

While the Qur'ānic address to man being generic covers both men and women, at places the Qur'ān specifically mentions both men and women separately. For example, in this verse $(33: 35)^{4} \mathrm{God}$ has addressed both pious men and women, promising them His forgiveness and great reward. This underscores the note of gender parity and equality in Islam. ${ }^{5}$

Both men and women are advised to believe in God and do good works in order to enter Paradise. Allah says:

He who does evil is punished equal to it. But one who does good, man or woman, and is a believer, will enter paradise. They will get there provision without any measure. (Ghäfir $40: 40)^{6}$ 
In the socio-economic spheres too, Islam has provisions for their betterment. Malladi Subbamma writes:

Muhammad (pbuh) did not only reform this (the practice of infanticide) but made provision for bettering the position of women in respect of inheritance and succession. He has laid down definite and specific rules in respect of the same. ${ }^{7}$

The marital relationship is most succinctly expressed in a phrase that has been widely quoted throughout the centuries. Allah says:

Men are the protectors and maintainers of women, for God has given excellence to one over the other, and because men spend their wealth on supporting them. So the pious women are obedient and guard and the rights of men in their absence under God's protection. If you fear their rebellion, (first) advise them, (next) refuse to share their beds, and (at last) beat them (lightly). If they return to obedience, do not look for ways to harm them. God is Most Exalted, the Greatest. (Al-Nisä' 4:34) ${ }^{8}$

Naseem Ahmad opines regarding the meaning of this verse that the headship of the husband should on no account be abused as a license for dictatorship: it does not signify absolute freedom on the part of the person in charge; if the husband misuses or abuses his status, the wife has the right to interfere to rectify the situation. After all, the whole issue of being a chairperson is to ensure the smooth running of the family. ${ }^{9}$

These are some of the concerns regarding the sociocultural background of women in the Qur'ān. So, to understand women and their dress code without internalizing these various concerns may mislead readers. The gender discourse of the Qur'ān can be understood by taking into account the context, co-text, history, comparative literature, sociology, ethnography, and biology where all creatures are created in pairs. The format of discourse to understand the women and their place in the Qur'ān 
can be diagrammatically represented thus:

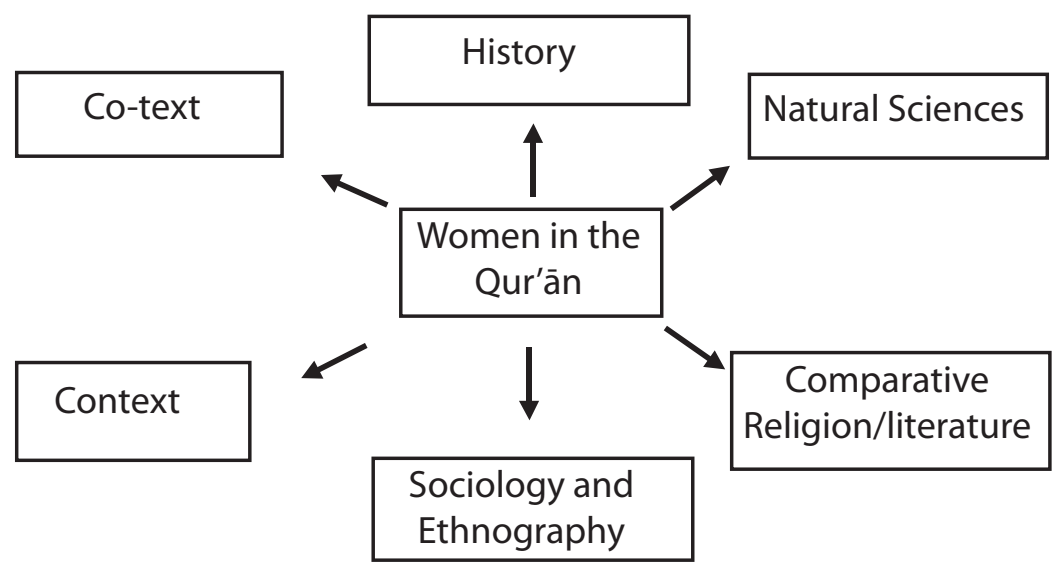

\section{Etymology of the Word Hijäb and its Meaning}

The Arabic word Hijäb is derived from the root Hajaba which means to cover or to screen. Thus Hijäb means partition, veil or curtain. ${ }^{10}$ It refers to a device that creates separation or privacy. ${ }^{11}$ The word appears seven times in the Qur'ān and has a common semantic theme of separation. The Qur'ān uses the word Hijäb to refer to a sense of separation, protection and covering that has both literal and metaphorical connotations. ${ }^{12}$ In the verse Maryam 19:17, Hijäb is used for a kind of seclusion. Allah says:

She [Maryam] placed a curtain, screening herself from people. God sent her His spirit which appeared before her as a human being in every respect. (Maryam 19:17) ${ }^{13}$

In the verses (17:45) and (41:5) Hijäb is used in its metaphorical sense to denote an invisible barrier. Allah says:

When you recite the Qur'ān, God places an invisible barrier between you and those who do not believe in the Hereafter. (Al Isrä' 17:45) $)^{14}$

The term Hijäb came to refer to the proper attire for modest Muslim women when they are in public, and rationale 
for the "dress code" is anchored in the interpretation of a number of Qur'ānic verses that apply to the Prophet's wives as well as to believing women in general. ${ }^{15}$

At the time of the crystallization of Islamic law, Qur'ānic Commentators were not certain what parts of the body a woman was supposed to cover. This imprecision and difference of opinion among exegetes continued for centuries: whether Zinat ${ }^{16}$ which draws attention to a woman encompasses the whole body or not. The dominant opinion among the jurists requires Muslim women to conceal their entire bodies with the exception of their feet, hands and faces. ${ }^{17}$

The ambiguity of the Qur'ānic text on the issue of Hijāb leaves room for a multiplicity of social, cultural, economic and geographical factors to define a precise code of behavior for Muslim women at a given time and place.

\section{Methodology}

For making a comparative analysis the verse $A / N u \bar{r}$ 24:31 is selected. Its translations and commentaries rendered by Abdullah Yusuf Ali (1872-1953), ${ }^{18}$ Taqiuddin al Hilali (1895-1990) and Muhammad Muhsin Khan (1925--), ${ }^{19}$ Muhammad Asad (1900-1992), ${ }^{20}$ Abul Ala Maududi (1903-1979) ${ }^{21}$ and Tarif Khalidi (1938--)22 are selected.

\subsection{The Rationale behind selecting this verse:}

The rationale behind selecting this verse is that the identity of woman in Islam is a hot topic of discussion in almost all parts of the world. Islam is often criticized for its stance towards woman.

\subsection{The Rational behind selecting these translations:}

These translations are chosen for conducting this study as representatives of various schools, viewpoints and methods of interpretation. Yusuf Ali represents the apologetic and pseudorational mindset ${ }^{23}$; meanwhile Taqiuddin al Hilali and Muhammad Muhsin Khan stand for Salafi tradition ${ }^{24}$. Abul Ala Maududi 
is traditional in approach and viewpoint ${ }^{25}$, at the same time Muhammad Asad is apologetic ${ }^{26}$ and Tarif Khalidi is modern ${ }^{27}$.

3.3 Paradigm of Analysis

Analysis will be made based on following:

a) Lexical level analysis: at this level emphasis will be given to only the morphemes/ phrases/ clauses that are crucial to discuss the message of the verse.

b) Discourse level analysis: at this level the discourse of the verse will be analyzed.

\section{Comparative Analysis}

The verse $A /$ Nür 24:31 and its various translations are affixed at the end. ${ }^{28}$

\subsection{Lexical Level Analysis}

The following key morphemes/phrases from the verse are needed to be analyzed.

\section{Yaḥfaẓna furūjahunna}

Yusuf Ali and Muhammad Asad take the sense of the phrase and translate it as 'guard their modesty' and 'to be mindful of their chastity' respectively. Yusuf Ali comments that modesty is needed for both men and women, but a greater amount of privacy is required for women. ${ }^{29}$ Hilali and Khan, Maududi and Tarif Khalidi take the phrase in the literal sense and render it as 'protect their private parts','guard their private parts' and 'safeguard their private parts' respectively. Hilali and Khan limit its meaning into sexual acts by giving parenthetical statement: 'from illegal sexual acts'. ${ }^{30}$ Maududi takes the phrase in the sense of Satr ${ }^{31}$ and he states that it includes both illegal sexual urges and exposition of Satr before others. He summarizes that believing women are asked to shun any illegal gratification of their sexual urges and to refrain from exposing their Satr before others. ${ }^{32}$ 


\section{Zinat}

Zinat is translated by Yusuf Ali by employing two words: beauty and adornments. He explains that' Zinatmeans both natural beauty and artificial ornaments'. He adds that'I think both [natural beauty and artificial ornaments] are implied here, but chiefly the former.33 But, it is not clear that why he puts the emphasis on natural beauty. Hilali and Muhsin Khan use the term 'adornment' which means, according to the Oxford Advanced Learner's Dictionary, something used to make somebody or something look more attractive by decorating them or it with something. ${ }^{34}$ So, the word 'adornment' occupies a sense of artificial beauty. Muhammad Asad goes for the word 'charm' which is idiomatic. Maududi renders it as 'adornment' and says that 'adornment' includes any means used by women to make themselves look attractive: good dress, ornaments and other cosmetics. ${ }^{35}$ 'Attraction' is the word used by Tarif Khalidi. 'An attractive thing' is something draws the attention of others. So Zinat is considered as something draws the attention, hence it possesses a semantic relation to the earlier phrase of the verse, 'not to expose'. Tarif Khalidi's rendering as 'attraction' includes the sense of the word Zinat i.e. natural beauty, ornaments, cosmetics etc. 'Adornment' highlights artificial decoration, 'charm' is idiomatic, 'beauty' is something abstract and 'attraction' (in the sense of the attraction of a thing) is anything (natural, or artificial) that draws attention. So, women are not allowed to expose anything, including their natural beauty and artificial adornment, which draws attention of others. Hence, 'beauty (both natural and artificial)' is the more appropriate rendering. The verse and its translations are affixed. ${ }^{36}$

\section{Illā mā zahara minhā}

The phrase is easy to translate but difficult to specify what body parts it refers to. Yusuf Ali translates it as 'except what (must ordinarily) appear thereof', without any comments. Hilali and Muhsin Khan render the phrase as 'except only that which is apparent' and specifies it thus 'like both eyes for necessity to see the way, or outer palms of hands or one eye or dress like veil, 
gloves, head cover, apron etc. ${ }^{\prime 37}$ But it is not clear what criteria are used to specify these body parts. Muhammad Asad uses the phrase 'beyond what may (decently) be apparent thereof' and goes forward to state that 'the deliberate vagueness of this phrase is meant to allow for all the time-bound changes that are necessary for man's moral and social growth'.38 Maududi uses the phrase 'except that which is revealed of itself' as similar to earlier renderings and points out to the ambiguous nature of the verse in his commentary. Maududi argues:

Obviously, the intent of the verse is what women themselves should not intentionally display their charms and beauty. However it is possible that certain attractive objects about them might nevertheless be revealed: for example, the outer garment might be blown up by the wind causing some of a women's adornments to be exposed. When such things happen, the women concerned are not to be blamed. This meaning of the Qur'ānic verse is ascribed to Abd Allah ibn Masud, Hassan al Basri, Muhmmad ibn Sirin and Ibrahimal Nakhai. ${ }^{39}$

So, to Maududi, the phrase Illā māz̧ahara minhā signifies the occasional or accidental case of 'revealed of itself' and he strictly affirms that 'it is not a permission to uncover that which is customary to keep uncovered' ${ }^{40}$. Tarif Khalidi renders it as 'except what is visible.' Tarif Khalidi points to the visible part of the body. His rendering does not disclose what are the parts indented. Almost all renderings are one and same but the semantic range cannot be fixed only by these renderings. Maududi and Hilali and Khan speaks of that the phrase suggests the injunction of covering the faces of women. They consider the traditional mainstream viewpoints regarding Hijäb, where as Asad takes the phrase as a token of liberalization and argues that it allows for time bound changes in the dress code of women. Yusuf Ali stresses the ways and customs of the society. Hilali and Khan and Maududi are traditional where as Asad is reformative in translating the phrase. Tarif Khalidi's rendering is ambiguous. 


\section{Khumur (singular Khimār)}

'Veil' is used for Khumur by Yusuf Ali, Hilali and Muhsin Khan and Maududi. The meaning of the word 'veil' is yet to be fixed. According to the Oxford Advanced Learner's Dictionary, a veil refers to a covering of very thin transparent material worn, especially by women, to protect or hide the face, or as part of a hat, etc.. ${ }^{41}$ So the English word 'veil' clearly includes a cloth which covers the face, but Arabic word Khumur does not. Muhammad Asad renders it as 'head coverings'; this is close to the original. He comments that the noun Khumur denotes the head covering customarily used by Arabian women before and after the advent of Islam. More user friendly word 'shawl' which means, according to the Oxford Advanced Learner's Dictionary, a large piece of cloth worn by a women around the shoulders or head ${ }^{42}$ is used by Tarif Khalidi. The question of its link with the next phrase "I $\bar{a}$ juyūbihinna,', also arises while using the word 'veil'. Because 'veil' denotes a cloth that covers face, where as Juyūb means bosom. Yusuf Ali, Hilali and Muhsin Khan and Maududi translate Khumur as 'veil' to promote the covering of the face as an injunction of the verse. Tarif Khalidi and Asad do not consider that the covering of the face as an injunction of the verse.

\section{5. 'lā juyūbihinna}

Yusuf Ali, Muhammad Asad and Maududi use the word 'their bosoms', where as Hilali and Muhsin Khan keep the original Arabic word and explain the meaning as 'their bodies, faces, necks and bosoms'. Hilali and Khan expand the meaning of Juyūb from 'bosoms' to face, neck and even to the entire body. To Tarif Khalidi, it is 'breast lines'. His rendering does not take the sense of the word because he limits the meaning to the breast lines. Here Hilali and Khan commits the mistake of expanding the meaning of Juyūb from 'bosoms' to face, neck and even to the entire body, as Asad does in restricting the meaning of Juyübto 'breast lines'. 


\subsection{Discourse Level Analysis}

The following questions arise regarding the issue of Hijäb.

1. Is there difference, in dress code of women and men?

2. What parts are referred to in the phrase 'Illā māzahara minhā?

3. Does the covering of the face come under the semantic range of this verse?

To Yusuf Ali modesty is needed for both men and women but in terms of privacy there are differences. He says that 'on account of the differentiation of the sexes in nature, temperaments and social life, a greater account of privacy is required for women than men.43 Other two questions are not addressed by Yusuf Ali whereas Hilali and Muhsin Khan concentrate on the rest. They state that face should be covered as per the injunction of the verse and provide two Hadith to emphasize the point.

Narrated Aishah (RA): 'May Allah bestow His mercy on the early emigrant women. When Allah revealed: "And to draw their veils all over Juyūbihinna (i.e. their bodies, faces, necks and bosoms)" - they tore their Murūt (a wooden dress, or a waist-binding cloth or an apron etc.) and covered their heads and faces with those torn Murūt'

Narrated Safiyyah bint Shaibah: 'Aishah used to say: 'When the verse "And to draw their veils all over Juyübihinna (i.e. their bodies, faces, necks and bosoms)" (v.24:31) was revealed, (the ladies) cut their waist sheets at the edges and covered their heads and faces with those cut pieces of cloth.'(Sahīh Al-Bukhārī, Vol.6, Hadīth No.282). ${ }^{44}$

The Arabic text of Hadith that they 'covered their head and faces with those cut piece of cloth', is 'Fakhtamarna bi hä' or 'made Khimär from it'. The Hadith therefore means that the women tore their sheets and made Khimār from the cut pieces. The word 
'faces' does not even appear in the original Arabic text of Hadith. Here it is very clear that Hilali and Khan deliberately expand the meaning of Juyūb from bosoms to 'to face, neck and even to body'. According to the Dictionary of Modern Written Arabic, Juyūb means breast or bottom. ${ }^{45}$ So, formal equivalency of the term is distorted. Hilali and Khan provide the parenthetical description of the phrase 'Juyübihinna' as 'their bodies, faces, necks and bosoms' in the translation of the verse and also in the translation of the Hadith provided. So, it is a deliberate and conscious attempt to include'face' under the term Juyūb. To them the verse includes the injunction of Niqäb i.e covering the face of women in public, and only the minimum, like the eyes are exception.

Muhammad Asad argues that the Islamic scholars tried to restrict the meaning of Illa māzahara minha $\bar{a}^{46}$ to the face, neck and sometimes less than that and he goes to the extent that it is allowed to decide the meaning of IIla mäzahara minh $\bar{a}^{47}$ as per the custom and socio-cultural background. He says:

Although the traditional exponents of Islamic Law have for centuries been inclined to restrict the definition of "what may (decently) be apparent" to a woman's face, hands and feet - and sometimes even less than that - we may safely assume that the meaning of Illā mäzahara minhā is much wider, and that the deliberate vagueness of this phrase is meant to allow for all the time-bound changes that are necessary for man's moral and social growth. ${ }^{48}$

He points out that the main injunction in the verse is to keep modesty and it will change according to place, time and custom. He argues:

The pivotal clause in the above injunction is the demand, addressed in identical terms to men as well as to women, to lower their gaze and be mindful of their chastity. ${ }^{49}$

He holds an open ended view, with respect to sociocultural and geographical change, regarding Hijäb. 
Maududi gives a detailed discussion on these four points: 1) Rules regarding women's looking at men and men's looking at women, 2) Satr, 3) The additional injunctions to women in terms of modesty, and 4) The body parts which come under the exception.

He provides a detailed account of rules about women's looking at men and men's looking at women by citing several Hadith. But it is clear that such a discussion does not directly come under the verse. He says:

When we bring all these traditions together, they suggest that the rules regarding women looking at men are not as strict as those regarding men looking at women. For example, women are not allowed to look at men in close proximity, say sitting in an assembly, but they can look from a distance, or look at men who are taking part in a lawful play or show. Additionally, if there is genuine necessity, they may look at men even if they are in the same house. ${ }^{50}$

He takes 'private parts' as Satr and provides a detailed discussion on it. Actually Satr is a different concept and that is not the subject matter of this verse. The injunction regarding Satr is applicable even in the case of men with whom marriage is forbidden. The injunction regarding Satr features in the verses 70:29-30 31 and $23: 5-6^{52}$. He opines that the modesty of women is different from that of men and states:

It is worth noting that the requirement of the Shari't with regard to women is different to what it requires of men. The Sharī't requires men to keep their looks away from the opposite sex and to guard their chastity. Women, however, are required to abide by some additional rules as well. This makes it quite clear that in this particular regard the sexes are not alike..$^{53}$

He takes the word Zinat in a wider sense. For him, it consists of 'those means used by women to make themselves look attractive: (i) good dress; (ii) ornaments, and (iii) other cosmetics 
used by women the world over to beautify their heads, faces, hands and feet. ${ }^{\prime 54}$ While referring to what parts are included in the exception, he states that 'the intent of the verse is that women themselves should not display intentionally their charms and beauty. ${ }^{\prime 55} \mathrm{He}$, like Hilali and Muhsin Khan, includes 'the face' in the semantic range of Juyūb. Tarif Khalidi takes the sense of the verse. To him 'attractions' of any kind, natural or artificial, that draws attention of others come under the discussion. So, women are not allowed to expose anything, including their natural beauty and artificial adornment, which draws the attention of others.

In my opinion, the correct meaning of this verse can also be understood in the light of following points:

1. Both women and men have to follow modesty.

2. In terms of privacy, there is difference between women and men.

3. Women themselves should not intentionally display their charms and beauty.

4. The face does not come under the term Juyūb.

5. 'Veil' is an ambiguous word to translate Khumur.

6. Zinat includes both natural beauty and artificial adornment.

\section{Conclusion}

5.1Differences in translating the term Zinat

'Adornment' (Yusuf Ali, Maududi, Hilali and Khan) highlights artificial decoration, 'charm' (Asad) is idiomatic, 'beauty' (Yusuf Ali) is something abstract and 'attraction' (Tarif Khalidi) (in the sense of the attraction of a thing) is anything (natural or artificial) that draws attention. The point is that as far as the differences in rendering the term into English, the semantic range of the verse varies. 
5.2 Differences in translating the phrase Illā māẓahara minhā

Hilali and Khan and Maududi consider the traditional mainstream viewpoints in translating the phrase, where as Asad takes the phrase as a token of liberalization and argues that it allows for time bound changes in the dress code of women. Yusuf Ali stresses the ways and customs of the society. Hilali and Khan and Maududi are traditional where as Asad is reformative in translating the phrase. Tarif Khalidi's rendering is ambiguous.

\subsection{Differences in translating the term Khumur}

Yusuf Ali, Hilali and Muhsin Khan and Maududi translate Khumur as 'veil' to promote the covering of the face as an injunction of the verse. Tarif Khalidi and Asad do not consider that the covering of the face as an injunction of the verse.

\subsection{Differences in the viewpoints of translators}

Hilali and Khan stand with traditional viewpoint and argue that the verse includes the injunction of covering the face of women in public. For proving the same, they mistranslate the term Juyūb and Khumur. Like them, Yusuf Ali and Maududi also speak for the orthodoxy. Asad is different from others and he takes the verse as a sign of liberalization and argues that dress code of women should be decided according to the prevailing culture and customs. So he is reformative in approach. Tarif Khalidi does not believe the covering of the face of women in public as an injunction of the verse.

In short, Modification of the Qur'ānic terms, negation of the semantic coherence of the Qur'ānic verse, mistranslation of Qur'ānic terms etc. are found in various translations. Translators find room for accommodating their ideologies and viewpoints in their translation of the Qur'ānic verse. 


\section{Appendix I}

The verse (AINūr 24:31) related to Hijäb and its translations without commentary that are used in the study

The Qur'anic Text

Verse (Al Nūr 24:31)

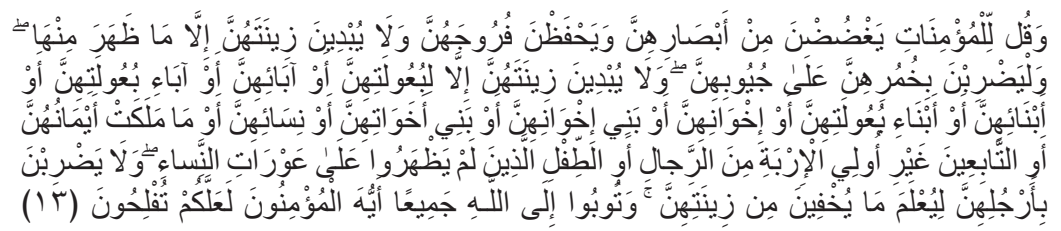

The Translated Texts and Commentary

1) Yusuf Ali $24: 31^{56}$

And say to the believing women that they should lower their gaze and guard (*2984) their modesty; that they should not display their beauty and ornaments $\left({ }^{*} 2985\right)$ except what (must ordinarily) appear thereof; that they should draw their veils over their bosoms and not display their beauty except to their husbands, their fathers, their husband's fathers, their sons, their husbands' sons, their brothers or their brothers' sons, or their sisters' sons, or their women, or the slaves whom their right hands possess, or male servants free of physical needs, or small children who have no sense of the shame of sex; and that they should not strike their feet in order to draw attention to their hidden ornaments. (*2986) And 0 ye Believers! Turn ye all together towards Allah, that ye may attain Bliss. $\left({ }^{*} 2987\right)$

2) Hilali and Muhsin Khan $24: 31^{57}$

And tell the believing women to lower their gaze (from looking at forbidden things), and protect their private parts (from illegal sexual acts) and not to show off their adornment except only that which is apparent (like both eyes for necessity to see the way, or outer palms of hands or one eye or dress like veil, 
gloves, head-cover, apron, etc.), and to draw their veils all over Juyūbihinna (i.e. their bodies, faces, necks and bosoms) and not to reveal their adornment except to their husbands, or their fathers, or their husband's fathers, or their sons, or their husband's sons, or their brothers or their brother's sons, or their sister's sons, or their (Muslim) women (i.e. their sisters in Islam), or the (female) slaves whom their right hands possess, or old male servants who lack vigor, or small children who have no sense of the feminine sex. And let them not stamp their feet so as to reveal what they hide of their adornment. And all of you beg Allah to forgive you all, $\mathrm{O}$ believers, that you may be successful $\left({ }^{*} 1\right)$.

3) Muhammad Asad 24:31 58

And tell the believing women to lower their gaze and to be mindful of their chastity, and not to display their charms [in public] beyond what may (decently) be apparent thereof; (*37) hence, let them draw their head-coverings over their bosoms. (*38) And let them not display (more of) their charms to any but their husbands, or their fathers, or their husbands' fathers, or their sons, or their husbands' sons, or their brothers, or their brothers' sons, or their sisters' sons, or their womenfolk, or those whom they rightfully possess, or such male attendants as are beyond all sexual desire, $\left({ }^{*} 39\right)$ or children that are as yet unaware of women's nakedness; and let them not swing their legs (in walking) so as to draw attention to their hidden charms (*40) And (always), 0 you believers -all of you -turn unto God in repentance, so that you might attain to a happy state! (*41)

4) Abul Ala Maududi 24:3159

And enjoin believing women to restrain their gaze $\left({ }^{*} 31\right)$ and guard their private parts (*32) and (*33) additionally not to reveal their adornment (*34) except that which is revealed of itself; (*35) let them draw their veils over their bosoms, (*36) and not to reveal their adornment to any save (*37) to their husbands, or their fathers, or the fathers of their husbands, $\left({ }^{*} 38\right)$ or of their own sons, or the sons of their husbands, $\left({ }^{*} 39\right)$ or their brothers, $\left({ }^{*} 40\right)$ or

\section{Translation Today}


the sons of their brothers, $\left({ }^{*} 41\right)$ or the sons of their sisters, $\left({ }^{*} 42\right)$ or the women with whom they associate, $\left({ }^{*} 43\right)$ or those that are in their bondage, $(* 44)$ or the male attendants in their service free of sexual desire, $\left({ }^{*} 45\right)$ or children that are yet unaware of private parts of women. $\left({ }^{*} 46\right)$ Nor should they stamp their feet on the ground in such manner that their hidden ornament becomes revealed. $\left({ }^{*} 47\right)$ Believers, turn together, all of you, to Allah in repentance that you may attain true success. $\left({ }^{*} 49\right)$

5) Tarif Khalidi $24: 31^{60}$

Tell believing women to avert their eyes, and safeguard their private parts, and not to expose their attractions except what is visible. And let them wrap their breast lines, and reveal their attractions only before their husbands and fathers, or fathers- in -law, or sons, or sons of their husbands, or brothers, or sons of brothers, or sons of sisters, or their womenfolk, or slaves, or male attendants with no sexual desire, or children with no intimate knowledge of private parts of women. And let them not stamp their feet to reveal what they hide of their ornaments.

\section{NOTES}

1. Ruth Roded, 'Women and the Qur'àn' in Encyclopedia of the Qur'ān. Ed. Jane Dammen McAuliffe. Leiden Boston: Brill, 2006. Vol. V. p, 523.

2. Ibid.,

3. A.R. Kidwai, What is in the Qur'än? Message of the Qur'än in Simple English. New Delhi: Viva Books, 2013. p.248.

4. The Qur'ān, Al Aḥzāb 33:35.

5. A.R. Kidwai, What is in the Qur'än? Message of the Qur'än in Simple English. New Delhi: Viva Books, 2013. p.248.

6. Ibid., p, 281.

7. Malladi Subbamma, Islam and Women. New Delhi: Sterling Publishers, 1988. p.84. 
8. A.R. Kidwai, What is in the Qur'än? Message of the Qur'ān in Simple English. New Delhi: Viva Books, 2013. p.47.

9. Naseem Ahmad, Women in Islam. New Delhi: A.P.H. Publishing Corporation, 2003. Vol.Il. p.527.

10. F. Steingass, Arabic English Dictionary. New Delhi: Cosmo Publications, 1978. p.264.

11. Mona Siddiqui,'Veil”, in Encyclopedia of the Qur'ān, Ed. Jane Dammen McAuliffe. Leiden Boston: Brill 2006. Vol.V. p.412.

12. Ibid.,

13. A.R. Kidwai, What is in the Qur'än? Message of the Qur'än in Simple English. New Delhi: Viva Books, 2013. p.172.

14. Ibid., p, 160.

15. Ruth Roded, 'Women and the Qur'àn', in Encyclopedia of the Qur'ān. Ed. Jane Dammen McAuliffe, Leiden Boston: Brill, 2006. Vol.V. p.526.

16. The Qur'ān, Al Nūr 24:31

17. Ruth Roded, "Women and the Qur'ān", in Encyclopedia of the Qur'ān. Ed. Jane Dammen McAuliffe., Leiden Boston: Brill, 2006. Vol.V. p.526.

18. Abdullah Yusuf Ali, The Holy Qur'än, Text, Translation and Commentary. Brentwood, U.S.A.: Amana Corporation, 1989.

19. Muhammad Taqiuddin Hilali and Muhammad Muhsin Khan, Translation of the Meanings of The Noble Qur'ān. Madinah, K.S.A: King Fahad Complex for the Printing of the Holy Qur'ān, 1427 A.H.

20. Muhammad Asad, The Message of the the Qur'ān, Gibraltar: Dar al- Andalus, 1980.

21. Sayyid Abul Ala Maududi, Towards Understanding the Qur'än. Tran. Zafar Ishaq Ansari, New Delhi: Markazi Maktaba Islami Publishers, 2004.

22. Tarif Khalidi, The Qur'än A New Translation. London: Penguin 
Books, 2008.

23. A.R. Kidwai, Translating the Untranslatable, A Critical Guide to 60 English Translations of the Qur'än. New Delhi: Sarup Book Publishers, 2011. p.16.

24. Ayaz Afsar and Muhammad Azmat, 'From the Word Allah to the Words of Men: The Qur'ān and the Poetics of Translation', Islamic Studies. 52:2, 2002. pp. 193-211.

25. A.R. Kidwai, Bibliography of the Translations of the Meanings of the Glorious Qur'än in to English: 1649-2002 A Critical Study. Madinah, K.S.A: King Fahad Qur'ān Printing Complex, 2005. p.242.

26. A.R. Kidwai, Translating the Untranslatable, A Critical Guide to 60 English Translations of the Qur'ān. New Delhi: Sarup Book Publishers, 2011. p.70.

27. Ibid., p.158.

28. Appendix I

29. Abdullah Yusuf Ali, The Holy Qur'ān, Text, Translation and Commentary. Brentwood, U.S.A.: Amana Corporation, 1989. p.873.

30. Appendix I

31. The literal meaning of the Arabic word Satr is something that is hidden or something which should be hidden. When used in the Islamic context, Satr means the parts of the human body which are obligatory on the believers to be hidden from everyone except his/her partner in marriage.

32. Abul Ala Maududi, Towards Understanding the Qur'ān. Trans. Zafar Ishaq Ansari. New Delhi: Markazi Maktaba Islami Publishers, 2004. p. 228.

33. Abdullah Yusuf Ali, The Holy Qur'ān, Text, Translation and Commentary. Brentwood, U.S.A.: Amana Corporation, 1989. p.873. 
34. A. S. Hornby, ed. Oxford Advanced Learner's Dictionary of Current English. Seventh Edition. Oxford: Oxford University Press, 2005. p. 21.

35. Abul Ala Maududi, Towards Understanding the Qur'ān. Trans. Zafar Ishaq Ansari. New Delhi: Markazi Maktaba Islami Publishers, 2004. p.229.

36. Appendix I

37. Muhammad Taqiuddin Hilali and Muhammad Muhsin Khan, Translation of the Meanings of The Noble Qur'ān. K.S.A: King Fahad Complex for the Printing of the Holy Qur'ān, 1427 A.H. pp. 395-396.

38. Muhammad Asad, The Message of the the Qur'än. Gibraltar: Dar al- Andalus, 1980. p.536.

39. Abul Ala Maududi, Towards Understanding the Qur'ān. Trans. Zafar Ishaq Ansari. New Delhi: Markazi Maktaba Islami Publishers, 2004. p.229

40. Ibid.,

41. A. S. Hornby, ed. Oxford Advanced Learner's Dictionary of Current English. Seventh Edition. Oxford: Oxford University Press, 2005. p.1696

42. Ibid., p. 1397

43. Abdullah Yusuf Ali, The Holy Qur'än, Text, Translation and Commentary. Brentwood, U.S.A.: Amana Corporation, 1989. p.873.

44. Muhammad Taqiuddin Hilali and Muhammad Muhsin Khan, Translation of the Meanings of The Noble Qur'än. K.S.A: King Fahad Complex for the Printing of the Holy Qur'ān, 1427 A.H. p. 396.

45. Hanswehr, A Dictionary of Modern Written Arabic. Ed. J.Milton Cowan. ILC,Spoken Language Service, 1976. p.150.

46. Al Nūr 24:31 
47. Al Nūr 24:31

48. Muhammad Asad, The Message of the the Qur'ān. Gibraltar: Dar al- Andalus, 1980. p.538.

49. Ibid,. p. 538.

50. Abul Ala Maududi, Towards Understanding the Qur'ān. Trans. Zafar Ishaq Ansari. New Delhi: Markazi Maktaba Islami Publishers, 2004. p.227.

51. The Qur'ān Al Ma'ā rij 70: 29-30

52. The Qur'ān Al Mu'minūn 23: 5-6

53. Abul Ala Maududi, Towards Understanding the Qur'ān. Trans. Zafar Ishaq Ansari. New Delhi: Markazi Maktaba Islami Publishers, 2004. p. 229.

54. Ibid,.

55. Ibid,.

56. Abdullah Yusuf Ali, The Holy Qur'än, Text, Translation and Commentary. Brentwood, U.S.A.: Amana Corporation, 1989. pp, 873-874.

57. Muhammad Taqiuddin Hilali and Muhammad Muhsin Khan, Translation of the Meanings of The Noble Qur'än. K.S.A: King Fahad Complex for the Printing of the Holy Qur'ān, 1427 A.H. pp. 395-396.

58. Muhammad Muhammad Asad, The Message of the the Qur'ân. Gibraltar: Dar al- Andalus, 1980. pp.538-539.

59. Abul Ala Maududi, Towards Understanding the Qur'ān. Trans. Zafar Ishaq Ansari. New Delhi: Markazi Maktaba Islami Publishers, 2004. pp. 227-242.

60. Tarif Khalidi, The Qur'än A new Translation, Penguin Books, London, 2008. p.284. 